\title{
Association between single nucleotide polymorphisms in the CXCR1 gene and somatic cell score in Holstein dairy cattle
}

\author{
I. Goertz, ${ }^{*}$ C. Baes, $†$ C. Weimann, ${ }^{*}$ N. Reinsch, $†$ and G. Erhardt*1 \\ *Department of Animal Breeding and Genetics, Justus-Liebig-University, 35390 Giessen, Germany \\ †Research Institute for Biology of Farm Animals, 18196 Dummerstorf, Germany
}

\begin{abstract}
In addition to its position in a quantitative trait locus for somatic cell score (SCS) and its function in the immune response, the $C X C R 1$ chemokine receptor gene located on Bos taurus autosome 2 is an auspicious candidate gene for udder health in dairy cattle. An association analysis was conducted in the German Holstein-Friesian population to test the association between the single nucleotide polymorphism (SNP) at position +777 within the $C X C R 1$ gene and the SNP at position -1768 in the $5^{\prime}$ upstream region of this gene (rs41255711) and the indicator trait SCS by using a granddaughter design. Data were analyzed for 3 families, with a total of 749 genotyped bulls and an extended pedigree of 8,071 animals from the national German bovine genome mapping project. Variance component estimation was used to determine the source of phenotypic variation in the chromosomal area of interest. A 20 -cM window surrounding the $2 \mathrm{SNP}$ in the CXCR1 gene was examined. Although the percentage of variance caused by the putative quantitative trait locus in the area studied was relatively large (12 and 11\%, respectively), no statistically significant association of the SNP CXCR1+ 7r7 or CXCR1-1768 with SCS was found. These results contradict previously published studies.
\end{abstract}

Key words: somatic cell score, dairy cow, $C X C R 1$

\section{INTRODUCTION}

Grosse et al. (1999) detected several SNP in diverse bovine cytokine genes, including the group of IL- 8 receptor genes $(I L 8 R)$. Together with its receptors, IL-8 plays a key role in immune response because of its role as an inducer of neutrophil chemotaxis and migration

Received July 8, 2008.

Accepted April 24, 2009.

${ }^{1}$ Corresponding author: Georg.Erhardt@agrar.uni-giessen.de
(Murphy, 1997). Neutrophils are key factors in nonspecific defense mechanisms against IMI (Paape et al., 2003), and a role of their receptors in mastitis development is plausible.

Using the predicted sequence of IL-8 receptor B (CXCR2), Grosse et al. (1999) mapped the genes for CXCR1 and CXCR2 approximately $90.3 \mathrm{cM}$ from the centromere of Bos taurus autosome 2. These genes are located within a chromosomal area containing a QTL for SCS in German and French Holstein-Friesians (Bennewitz et al., 2003). Comparison of the recently available bovine genome sequence with the human CXCR1 and CXCR2 sequences revealed the gene CXCR2 to be annotated incorrectly and actually to be CXCR1 (Rambeaud and Pighetti, 2007).

One of the SNP detected by Grosse et al. (1999) is a nonsynonymous polymorphism. Several studies have investigated associations between this SNP at position +777 in CXCR1 and SCS in cattle (Youngerman et al., 2004; Leyva-Baca et al., 2007, 2008). Youngerman et al. (2004) found a significant association of genotypes at position +777 in $C X C R 1$ with subclinical mastitis $(P<0.05)$ and SCS $(P<0.001)$, respectively, in US Holstein-Friesians. Cows expressing the genotype CC exhibited an increased incidence of subclinical mastitis compared with those with a GG genotype at the same position. Cows expressing genotypes GG and GC had greater SCS than those with the CC genotype; however, only cows expressing the GC genotype had a significantly greater SCS than those with genotype CC. In contrast, Leyva-Baca et al. $(2007,2008)$ found no association between the same SNP and SCS in Canadian Holsteins. Furthermore, they detected more SNP in the $5^{\prime}$ upstream region of the CXCR1 gene (Leyva-Baca et al., 2008). They revealed an association of the SNP CXCR1-1768 (rs41255711) with EBV for SCS in Canadian Holsteins in the first and second lactation and over all 3 lactations.

The aim of this study was to validate the relationship between CXCR1 and SCS previously reported in the German Holstein-Friesian population. Therefore, a large data set from the national German bovine genome mapping project was used. 
Table 1. Cycling conditions for typing the SNP CXCR1+77ry and CXCR1-1768

\begin{tabular}{lccccc}
\hline & \multicolumn{2}{c}{ CXCR1+7777 } & & \multicolumn{2}{c}{ CXCR1-1768 } \\
\cline { 2 - 3 } \cline { 5 - 6 } Item & Temperature, ${ }^{\circ} \mathrm{C}$ & Time $^{1}$ & & Temperature, $^{\circ} \mathrm{C}$ & Time $^{1}$ \\
\hline Initial denaturation & 94 & $90 \mathrm{~s}$ & & 95 & 15 min \\
Denaturation & 94 & $15 \mathrm{~s}$ & & 94 & $15 \mathrm{~s}$ \\
Annealing & 62 & $20 \mathrm{~s}$ & & 60 & $20 \mathrm{~s}$ \\
Elongation & 72 & $40 \mathrm{~s}$ & & 72 & $20 \mathrm{~s}$ \\
Final elongation & 72 & $5 \mathrm{~min}$ & & 72 & 5 min \\
\hline
\end{tabular}

${ }^{1} 35 \times$ denaturation, annealing, and elongation.

\section{MATERIALS AND METHODS}

\section{Animal Selection}

Three paternal half-sib German Holstein families containing 124 (BC), 273 (BD), and 352 (DA) animals were selected based on results of a joint analysis of 2 different granddaughter designs (Thomsen et al., 2000; Boichard et al., 2003) for 5 milk production traits, including SCS (Bennewitz et al., 2003). For these families, a genome-wise significant QTL for SCS on Bos taurus autosome 2 was detected. Deoxyribonucleic acid was available from the German bovine genome mapping project. The pedigree and phenotype information were obtained from the genetic computing center (VIT) in Verden, Germany. The phenotype for each genotyped offspring was provided as a daughter yield deviation for SCS, which is the average phenotype of daughters corrected for fixed effects such as herd, season, and calving interval, and for genetic contributions of the daughters' dams. Forty-eight unrelated German Holstein-Friesians were selected for allele frequency estimation.

\section{Polymorphism Detection and Genotyping}

To verify the SNP CXCR1+ 7r7, a PCR was established. Forward and reverse primers were designed using Primer 3 (http://frodo.wi.mit.edu/cgi-bin/primer3/ primer3_www.cgi). The PCR was performed with the primers BT_CXCR1_F $=$ 5'-GAGGCCTATCAACCACCGTA-3' and BT_CXCR1_R = 5'-GCGATCAGGACCAGGTTGTA-3' to amplify a 265-bp product containing the SNP. The regular volume of each PCR reaction was $25 \mu \mathrm{L}$, which included $20 \mathrm{ng}$ of genomic DNA, $2.5 \mu \mathrm{L}$ of $10 \times$ Taq Buffer advanced (Eppendorf AG, Hamburg, Germany), $200 \mu M$ each deoxynucleotide $5^{\prime}$-triphosphate, $0.8 \mu \mathrm{M}$ each primer, and $1 \mathrm{U}$ of Taq DNA polymerase (Eppendorf AG).

To type the SNP CXCR1-1768, a tetra-primer amplification refractory mutation system-PCR was established, using the primers published by Leyva-Baca et al. (2008). The reactions were carried out in a final volume of $15 \mu \mathrm{L}$ containing $20 \mathrm{ng}$ of genomic DNA,
$7.5 \mu \mathrm{L}$ of Absolute Q-PCR Mix (Abgene, ThermoFisherScientific, Hamburg, Germany), $0.4 \mu M$ each outer primer, and $0.8 \mu M$ each inner primer. Cycling for both SNP was performed in a thermocycler (iCycler, BioRad, Munich, Germany). Cycling conditions are shown in Table 1.

To detect the SNP CXCR1+77\%, the PCR product was digested with the restriction enzyme Bsp1286I, which distinguishes allele $\mathrm{C}$ and $\mathrm{G}$ of the SNP. The fragments were separated on a $3.5 \%$ agarose gel. The restriction enzyme cut at both the SNP and position 219 of the PCR product, resulting in fragment lengths of 219 and $47 \mathrm{bp}$ for the $\mathrm{G}$ allele and 180, 47, and $39 \mathrm{bp}$ for the $\mathrm{C}$ allele. Genotypes of the SNP CXCR1-1768 were detected on a $2 \%$ agarose gel as described by Leyva-Baca et al. (2008).

\section{Statistical Analysis}

Allele frequency for the polymorphisms $C X C R 1+777$ and $C X C R-1768$ were determined by direct counting. Variance component analysis was conducted to estimate the polygenic effect, effects of the putative QTL, and the effect of the residual environmental variance on SCS. Genotypes of CXCR1+7r7y and CXCR1-1768 were included as fixed effects. Polygenic variance was calculated using an extended pedigree including nongenotyped ancestors of genotyped animals $(\mathrm{n}=$ 8,071 ). The condensed gametic relationship matrix was calculated at every centimorgan within a $20-\mathrm{cM}$ window surrounding CXCR 1 by using the Fortran 90 software COBRA (Baes and Reinsch, 2007). The following linear mixed model was applied in ASReml (Gilmour et al., 2006) for the estimation of variance components:

$$
\mathrm{y}_{\mathrm{ijk}}=\mu+\mathrm{CX}_{\mathrm{i}}+\mathrm{a}_{\mathrm{j}}+\mathrm{g}_{\mathrm{k}}+\mathrm{e}_{\mathrm{ijk}}
$$

where $\mu$ is the overall mean, $\mathrm{CX}_{\mathrm{i}}$ is the fixed effect of the CXCR1+ 777 and $C X C R 1-1768$ genotype i, respectively, $a_{j}$ is the random polygenic effect of animal $j, g_{k}$ is the random gametic effect of gamete $\mathrm{k}$, and $\mathrm{e}_{\mathrm{ijk}}$ is the random residual. The random QTL effect was included to separate family-specific linkage disequilibrium from 
Table 2. Marker and QTL position within a 20-cM window surrounding $C X C R 1$, as well as $F$ - and $P$-values for the fixed effect of the SNP CXCR1+777 and CXCR1-1768, respectively, at each QTL position

\begin{tabular}{lccc}
\hline Marker and QTL & Position, cM & $F$-value, $+777 /-1768$ & $P$-value, $+777 /-1768$ \\
\hline DIK5133 & 28.744 & & \\
1 & 34.000 & $1.07 / 2.98$ & $0.342 / 0.086$ \\
TGLA226 & 34.978 & $1.07 / 3.00$ & $0.344 / 0.085$ \\
2 & 35.000 & $1.09 / 3.02$ & $0.335 / 0.084$ \\
3 & 36.000 & & \\
DIK4880 & 36.616 & $1.11 / 3.05$ & $0.330 / 0.082$ \\
4 & 37.000 & $1.12 / 3.09$ & $0.328 / 0.080$ \\
DIK4726 & 37.914 & $1.13 / 3.18$ & $0.323 / 0.076$ \\
5 & 38.000 & $1.14 / 3.21$ & $0.320 / 0.075$ \\
6 & 39.000 & $1.15 / 3.25$ & $0.318 / 0.073$ \\
7 & 40.000 & $1.15 / 3.3$ & $0.316 / 0.071$ \\
8 & 41.000 & $1.17 / 3.32$ & $0.311 / 0.070$ \\
TGLA110 & 41.614 & $1.18 / 3.34$ & $0.307 / 0.069$ \\
9 & 42.000 & $1.19 / 3.38$ & $0.304 / 0.067$ \\
10 & 43.000 & $1.21 / 3.46$ & $0.298 / 0.064$ \\
11 & 43.439 & & \\
12 & 44.000 & $1.22 / 3.47$ & $0.296 / 0.064$ \\
13 & 45.000 & $1.22 / 3.46$ & $0.296 / 0.064$ \\
MM8D3 & 45.264 & $1.22 / 3.46$ & $0.295 / 0.064$ \\
14 & 46.000 & $1.21 / 3.42$ & $0.298 / 0.066$ \\
15 & 47.000 & & \\
16 & 48.000 & $1.22 / 3.39$ & $0.296 / 0.067$ \\
17 & 49.000 & $1.23 / 3.37$ & $0.294 / 0.068$ \\
BM1223 & 49.306 & $1.23 / 3.34$ & $0.293 / 0.069$ \\
18 & 50.000 & $1.23 / 3.33$ & $0.292 / 0.069$ \\
19 & 51.000 & & \\
20 & 52.000 & & \\
BMS1987 & 53.000 & & \\
\hline 11 & 56.605 & & \\
\hline
\end{tabular}

${ }^{1} 11=$ position of the SNP that is included as a fixed effect in the model.

the population-wide linkage disequilibrium modeled as the fixed SNP effect. A total of 21 putative QTL positions were calculated within the $20 \mathrm{cM}$ surrounding CXCR1. Marker and putative QTL positions for the calculation of transmitting probabilities are shown in Table 2. Each QTL was calculated based on the markers $5 \mathrm{cM}$ left and right of the given position.

Phenotypic values were weighted as described in Bennewitz et al. (2004), with genetic parameters for covariance matrices as in Reents et al. (1995). The inclusion of both the polygenic effect and the QTL effect helped to avoid spurious false-positive results for association (I. MacLeod, Primary Industries Research, Victoria, Australia; personal communication).

\section{RESULTS AND DISCUSSION}

The sires of the families BD and DA carried the genotype $\mathrm{GC}$ at $C X C R 1+77 \%$, whereas the sire of the family $\mathrm{BC}$ was a homozygote for the $\mathrm{C}$ allele. The $\mathrm{C}$ allele had a frequency of $53 \%$ in the examined families, which is similar to the frequency observed by LeyvaBaca et al. $(2007,2008)$ in Canadian Holsteins. At position $C X C R 1-1768$, all 3 sires were homozygotes for the $\mathrm{T}$ allele. The allele frequency of the $\mathrm{T}$ allele at position
CXCR1-1768 was $84 \%$. Estimated allele frequencies in each family are shown in Table 3 .

Variance component analysis clearly showed that the genotypes examined had no significant effect on SCS on a population-wide basis (Table 2). This confirms the studies of Leyva-Baca et al. (2007, 2008) concerning the SNP CXCR1+777 in Canadian Holsteins. It contradicts their results regarding the SNP CXCR1-1768, for which they found an association with SCS in the first and second lactations and over all 3 lactations.

Total genetic variance (polygenic genetic variance plus 2 times the gametic variance) ranged from 0.0926 to 0.0997, with an average of 0.0972 for the SNP CXCR1+77\%. The QTL variance (2 times the gametic variance) for the same SNP was estimated at between 0.0089 and 0.0128 , with an average of 0.0114 . The re-

Table 3. Observed allele frequencies of the SNP CXCR1+777 and CXCR1-1768 in each family

\begin{tabular}{lcc}
\hline Family & CXCR1+777 & CXCR1-1768 \\
\hline BC & $\mathrm{C}=0.67$ & $\mathrm{~T}=0.83$ \\
$\mathrm{BD}$ & $\mathrm{C}=0.51$ & $\mathrm{~T}=0.83$ \\
$\mathrm{DA}$ & $\mathrm{C}=0.49$ & $\mathrm{~T}=0.85$ \\
\hline
\end{tabular}


sidual variance was estimated at between 0.2420 and 0.3230 , with an average of 0.2700 .

For the SNP CXCR1-1768, total genetic variance was estimated at between 0.0947 and 0.1024 , with an average of 0.1 . The QTL variance ranged between 0.0086 and 0.0125 , whereas the average was 0.0111 . Residual variance was estimated at between 0.2059 and 0.2955 , with an average of 0.2246 .

These results indicate that the QTL reported by Bennewitz et al. (2003) is indeed in or very close to the chromosomal area under investigation, but is not one of the SNP examined here. The discrepancy between our results and those of Youngerman et al. (2004) concerning the SNP CXCR1+7r7 may be due to differences in approach and sample size. The same discrepancy was seen when comparing the studies of Youngerman et al. (2004) and Leyva-Baca et al. (2007, 2008). In the latter studies, the sample size and the information content of the material (EBV) were also larger. The data set for SCS used in our study was adjusted for fixed effects, such as herd, season, and calving interval, and for genetic contributions of the daughters' dams to out an influence of these effects on the results. Using the uncorrected SCS could lead to false associations if additional effects biased the real effect of the genotype on a trait.

Because we were unable to detect an association between the daughter yield deviation for SCS and the genotype of $C X C R 1-1768$, the findings of Leyva-Baca et al. (2008) could also be due to linkage among the SNP and a causative mutation in their material. Because of the low frequency of the A allele at position -1768, it is feasible that the A alleles in their material belonged to only one or a small number of ancestors; therefore, the association could be a result of the sire effect.

The close proximity of $C X C R 1$ to the natural resistance-associated macrophage protein $(N R A M P)$ and the transition protein (TNP) 1 genes (Grosse et al., 1999), which are mainly involved in immune defense, suggests possible participation of one of these genes. This hypothesis could add the SNP at positions +777 and -1768 to markers for other causal mutations in the examined populations, but not in our families. Furthermore, despite intensive gene flow, New World and Old World Holstein-Friesian populations are significantly different (Hanslik et al., 2000). Kaupe et al. (2004) revealed the same trend concerning the DGAT1 locus. A possible explanation for the different results in the studies discussed could be that the US Holstein-Friesian and the German Holstein populations are based on different founders. Linkage of the A allele of CXCR1-1768 with a causative mutation may have remained in the US Holstein-Friesian population. The A allele in our material came only from the dams; therefore, we may have had no linkage in our material, even though our sires had a US origin. Although no population-wide linkage disequilibrium exists between $C X C R 1+777$ or CXCR1-1768 and the trait SCS in German Holsteins, other polymorphisms in or close to this region may be associated with udder health traits in dairy cows. Therefore, further investigation of this chromosomal area could provide new possibilities in effective markerassisted selection schemes for udder health traits.

\section{CONCLUSIONS}

In conclusion, an association analysis concerning the SNP $C X C R 1+777$ and $C X C R 1-1768$ with the SCS was performed using a mixed linear model that included a random QTL effect. The study revealed no association of the SNP with SCS. Although the causal mutation responsible for the quantitative effects of SCS has not yet been identified, we propose that $C X C R 1$ may be a feasible candidate gene for udder health or may be in close linkage disequilibrium to such a gene.

\section{ACKNOWLEDGMENTS}

This research was financially supported within the Fugato project M.A.S.-Net by the Förderverein Biotechnologieforschung (FBF) and the German Ministry of Education and Research (BMBF). The authors acknowledge the VIT (Verden, Germany) and the German Breeders Association (Bonn, Germany) for providing data and material.

\section{REFERENCES}

Baes, C., and N. Reinsch. 2007. Computing the condensed conditional gametic QTL relationship matrix and its inverse. Arch. Tierz. 50:294-308.

Bennewitz, J., N. Reinsch, C. Grohs, H. Leveziel, A. Malafosse, H. Thomsen, N. Xu, C. Looft, C. Kühn, G. A. Brockmann, M. Schwerin, C. Weimann, S. Hiendleder, G. Erhardt, I. Medjugorac, I. Russ, M. Förster, B. Brenig, F. Reinhardt, R. Reents, G. Averdunk, J. Blümel, D. Boichard, and E. Kalm. 2003. Combined analysis of data from two granddaughter designs: A simple strategy for QTL confirmation and increasing experimental power in dairy cattle. Genet. Sel. Evol. 35:319-338.

Bennewitz, J., N. Reinsch, S. Paul, C. Looft, B. Kaupe, C. Weimann, G. Erhardt, G. Thaller, C. Kühn, M. Schwerin, H. Thomsen, F. Reinhardt, R. Reents, and E. Kalm. 2004. The DGAT1 K232A mutation is not solely responsible for the milk production quantitative trait locus on the bovine chromosome 14 . J. Dairy Sci. 87:431-442.

Boichard, D., C. Grohs, F. Bourgeois, F. Cerqueira, R. Faugeras, A. Neau, R. Rupp, Y. Amigues, M. Y. Boscher, and H. Leveziel. 2003. Detection of genes influencing economic traits in three French dairy cattle breeds. Genet. Sel. Evol. 35:77-101.

Gilmour, A. R., B. J. Gogel, B. R. Cullis, and R. Thompson. 2006. ASReml User Guide, Release 2.0. VSN International Ltd., Hemel Hempstead, UK.

Grosse, W. M., S. M. Kappes, W. W. Laegreid, J. W. Keele, C. G. Chitko-McKown, and M. P. Heaton. 1999. Single nucleotide 
polymorphism (SNP) discovery and linkage mapping of bovine cytokine genes. Mamm. Genome 10:1062-1069.

Hanslik, S., B. Harr, G. Brem, and C. Schlötterer. 2000. Microsatellite analysis reveals substantial genetic differentiation between contemporary New World and Old World Holstein Friesian populations. Anim. Genet. 31:31-38.

Kaupe, B., A. Winter, R. Fries, and G. Erhardt. 2004. DGAT1 polymorphism in Bos indicus and Bos taurus cattle breeds. J. Dairy Res. 71:182-187.

Leyva-Baca, I., F. Schenkel, J. Martin, and N. A. Karrow. 2008. Polymorphisms in the $5^{\prime}$ upstream region of the $C X C R 1$ chemokine receptor gene, and their association with somatic cell score in Holstein cattle in Canada. J. Dairy Sci. 91:407-417.

Leyva-Baca, I., F. Schenkel, B. S. Sharma, G. B. Jansen, and N. A Karrow. 2007. Identification of single nucleotide polymorphisms in the bovine CCL2, IL8,CCR2 and IL8RA genes and their association with health and production in Canadian Holsteins. Anim. Genet. 38:198-202.

Murphy, P. M. 1997. Neutrophil receptors for interleukin-8 and related CXC chemokines. Semin. Hematol. 34:311-318.
Paape, M. J., D. D. Bannerman, X. Zhao, and J. W. Lee. 2003. The bovine neutrophil: Structure and function in blood and milk. Vet. Res. 34:597-627.

Rambeaud, M., and G. M. Pighetti. 2007. Differential calcium signaling in dairy cows with specific CXCR1 genotypes potentially related to interleukin-8 receptor functionality. Immunogenetics 59:53-58.

Reents, R., J. C. Dekkers, and L. R. Schaeffer. 1995. Genetic evaluation for somatic cell score with a test day model for multiple lactations. J. Dairy Sci. 78:2858-2870.

Thomsen, H., N. Reinsch, N. Xu, C. Looft, S. Grupe, C. Kühn, G. A. Brockmann, M. Schwerin, B. Leyhe-Horn, S. Hiendleder, G. Erhardt, I. Medjugorac, I. Russ, M. Förster, B. Brenig, F. Reinhardt, R. Reents, J. Blümel, G. Averdunk, and E. Kalm. 2000. A male bovine linkage map for the ADR granddaughter design. J. Anim. Breed. Genet. 117:289-306.

Youngerman, S. M., A. M. Saxton, S. P. Oliver, and G. M. Pighetti. 2004. Association of CXCR2 polymorphisms with subclinical and clinical mastitis in dairy cattle. J. Dairy Sci. 87:2442-2448. 